\title{
Effect of reducing dietary forage in lower starch diets on performance, ruminal characteristics, and nutrient digestibility in lactating Holstein cows
}

\author{
E. R. Farmer, ${ }^{*}$ H. A. Tucker, ${ }^{*}$ H. M. Dann, ${ }^{* 1}$ K. W. Cotanch, ${ }^{*}$ C. S. Mooney, ${ }^{*}$ A. L. Lock, † K. Yagi,‡ \\ and R. J. Grant* \\ *William H. Miner Agricultural Research Institute, Chazy, NY 12921 \\ †Department of Animal Sciences, Michigan State University, East Lansing 48824 \\ †ZEN-NOH National Federation of Agricultural Co-operative Associations, Tokyo 100-6832, Japan
}

\begin{abstract}
This experiment evaluated the effect of feeding a lower starch diet (21\% of dry matter) with different amounts of forage $(52,47,43$, and $39 \%$ of dry matter) on lactational performance, chewing activity, ruminal fermentation and turnover, microbial $\mathrm{N}$ yield, and totaltract nutrient digestibility. Dietary forage consisted of a mixture of corn and haycrop silages, and as dietary forage content was reduced, chopped wheat straw (0-10\% of dry matter) was added in an effort to maintain chewing activity. Dietary concentrate was adjusted (corn meal, nonforage fiber sources, and protein sources) to maintain similar amounts of starch and other carbohydrate and protein fractions among the diets. Sixteen lactating Holstein cows were used in replicated $4 \times$ 4 Latin squares with 21-d periods. Dry matter intake increased while physically effective neutral detergent fiber $\left(\mathrm{peNDF}_{1.18}\right)$ intake was reduced as forage content decreased from 52 to $39 \%$. However, reducing dietary forage did not influence milk yield or composition, although we observed changes in dry matter intake. Time spent chewing, eating, and ruminating (expressed as minutes per day or as minutes per kilogram of NDF intake) were not affected by reducing dietary forage. However, addition of chopped wheat straw to the diets resulted in greater time spent chewing and eating per kilogram of peNDF ${ }_{1.18}$ consumed. Reducing dietary forage from 52 to $39 \%$ did not affect ruminal $\mathrm{pH}$, ruminal digesta volume and mass, ruminal pool size of NDF or starch, ruminal digesta mat consistency, or microbial $\mathrm{N}$ yield. Ruminal acetate-to-propionate ratio was reduced, ruminal turnover rates of NDF and starch were greater, and total-tract digestibility of fiber diminished as dietary forage content decreased. Reducing the dietary forage content from 52 to $39 \%$ of dry matter, while increasing wheat straw inclusion to maintain chewing
\end{abstract}

Received January 20, 2014

Accepted May 15, 2014.

${ }^{1}$ Corresponding author: dann@whminer.com and rumen function, resulted in similar milk yield and composition although feed intake increased. With the lower starch diets in this short-term study, the minimal forage content to maintain lactational performance was between 39 and $43 \%$.

Key words: low starch diet, low forage diet, rumen dynamics, digestibility

\section{INTRODUCTION}

Increased ethanol production in the United States and the resulting higher price for corn has led to replacement of corn grain by non-forage fiber sources (NFFS) resulting in lower starch diets for lactating dairy cows (Dann et al., 2008; Bradford and Mullins, 2012). Lower starch diets (20-23\% of DM) generally do not adversely affect lactational performance or ruminal fermentation compared with higher starch diets $(>25 \%$ of DM; e.g., Gencoglu et al., 2010), but the combination of feeding lower starch and lower forage diets is relatively unexplored. Although dairy cows and rumen microbes do not have a specific requirement for starch, it is important to provide adequate total fermentable carbohydrates in the diet. Previous research supports replacement of the rapidly fermentable carbohydrates provided by corn grain with digestible carbohydrates from NFFS with the expectation of little alteration in milk production (Voelker and Allen, 2003; Dann et al. 2008; Gencoglu et al., 2010).

Ruminal $\mathrm{pH}$ is lower when the forage-to-concentrate ratio is decreased (Yang and Beauchemin, 2007, 2009). Moreover, reductions in ruminal $\mathrm{pH}$ below $\sim 5.8$ for greater than $5.24 \mathrm{~h} / \mathrm{d}$, especially when combined with high milk production, may result in subacute ruminal acidosis, leading to compromised efficiency of microbial fermentation, fiber digestion, and nutrient utilization (Yang and Beauchemin, 2007; Plaizier et al., 2008; Zebeli et al., 2008). Providing sufficient physically effective NDF ( $\left.\mathbf{p e N D F}_{1.18}\right)$, defined as the particle size of the fiber $>1.18 \mathrm{~mm}$, supports normal ruminal function due to longer forage particles enhancing chewing 
during eating and ruminating, salivary buffer secretion reducing acid production, and ruminal digesta mat formation (Mertens, 1997).

Feeding higher forage diets results in greater peNDF in the diet, but high-producing cows may be physically unable to consume enough of a higher forage diet to optimize milk production due to limited gut capacity (Allen, 2000). Additionally, poor forage growing and harvesting conditions may result in limited availability of forage. Nonforage fiber sources can partially replace forage fiber, resulting in increased ration nutrient density while allowing for adequate DMI (Kononoff et al., 2006; Zebeli et al., 2012), but these NFFS do not promote chewing activity due to their small particle size and high digestibility.

Mertens (1997) reported that not all forage NDF sources, at the same particle size, stimulate chewing activity equally. For example, oat straw stimulated more chewing per kilogram of NDF than did legume or grass hays. Based on this difference in chewing response, it is possible that replacing a portion of dietary grass or legume forage with straw could maintain chewing activity as total forage proportion in the diet is reduced.

Therefore, the objective of this study was to determine the short-term effect of feeding lactating Holstein cows diets containing lower starch content $(20.9 \%$ of dietary DM) and differing amounts of forage $(52,47$, 43 , and $39 \%$ of $\mathrm{DM}$ ) on lactation performance, chewing activity, ruminal fermentation and dynamics, microbial nitrogen yield, and total-tract nutrient digestibility. We hypothesized that reduced dietary forage percentage when combined with a lower starch diet and inclusion of chopped wheat straw would support chewing activity, ruminal function, and SCM production similar to higher forage diets.

\section{MATERIALS AND METHODS}

\section{Animal Use and Handling}

Eight primiparous (4 ruminally fistulated) and 8 multiparous (4 ruminally fistulated) Holstein cows, averaging $116 \pm 5$ DIM and $1.9 \pm 0.3$ lactations, were housed in individual tie stalls at the William H. Miner Agricultural Research Institute (Chazy, NY) from August 1 to October 24, 2008. Cows were stratified by parity, fistulation status, and milk production and used in a replicated $4 \times 4$ Latin square design to evaluate the effects of decreasing forage content of lower starch diet. Each square consisted of four 21-d periods with 12 $\mathrm{d}$ of adjustment to treatment followed by $9 \mathrm{~d}$ of data collection. Animal care and handling protocols were approved by the William H. Miner Agricultural Research Institute Animal Care and Use Committee.

\section{Diet Formulation}

Dietary treatments (Table 1) were formulated to contain $21 \%$ starch and vary in forage content (52, 47,43 , and $39 \%$ of DM). Diets were formulated using the CPM-Dairy nutrition model (version 3.0; Cornell University, Ithaca, NY; University of Pennsylvania, Philadelphia, PA; and William H. Miner Agricultural Research Institute, Chazy, NY) to supply the required nutrients for a lactating Holstein cow weighing $578 \mathrm{~kg}$ with a BCS of 3.0 , at 90 DIM consuming $22.0 \mathrm{~kg} / \mathrm{d}$ of $\mathrm{DM}$, and producing $40.8 \mathrm{~kg} / \mathrm{d}$ milk containing $3.8 \%$ fat and $3.0 \%$ true protein. These values ensured that first-lactation animals would have an adequate supply of required nutrients. Diets were formulated such that, as corn silage and haycrop silage content of the diets decreased, wheat straw inclusion increased. The concentrate portion of the diets was adjusted to maintain similar concentrations of starch, other carbohydrate fractions, and protein fractions (Tables 2 and 3 ). Diets were delivered as a TMR once daily (1030 h; Calan Data Ranger; American Calan Inc., Northwood, NH) allowing for ad libitum intake; free access to fresh water was provided. Dry matter intake was determined by difference from feed offered and refused for each cow during each data collection period.

\section{Milk Production and Composition}

Cows were milked 3 times daily $(0430,1230$, and 2030 h). Milk yields were recorded electronically (ProVantage Information Management System; BouMatic, Madison, WI) on d 13 to 19 of each period. Milk samples from 6 consecutive milkings for each cow were collected on d 16 (1230 and $2030 \mathrm{~h})$, d 17 (0430, 1230, and $2030 \mathrm{~h})$, and $\mathrm{d} 18(0430 \mathrm{~h})$ of each period. The first 3 consecutive milk samples and the last 3 consecutive milk samples were separately composited in proportion to milk yield at each sampling and preserved (BronolabW II Liquid Preservative; D\&F Control Systems Inc., Dublin, CA). Composited milk samples were analyzed for fat, true protein, lactose, SNF, urea N, and SCC by infrared procedures (Dairy One, Ithaca, NY; Foss 4000; Foss Technology, Eden Prairie, MN).

\section{$B W$ and $B C S$}

Body weight was measured (ID3000 indicator and MP600 58.4-cm load bars; Tru-Test Inc., Mineral Wells, TX) and BCS assigned in 0.25-unit increments on a scale of 1 to 5 (Ferguson et al., 1994) for each cow at $\mathrm{d} 1$ and $19(1200 \mathrm{~h})$ of each period. Three trained individuals assigned BCS independently throughout the study. 
Table 1. Ingredient composition of diets (\% of DM) fed to lactating Holstein cows

\begin{tabular}{lcccc}
\hline & \multicolumn{4}{c}{ Forage in diet (\%) } \\
\cline { 2 - 5 } Ingredient (\%) & 52 & 47 & 43 & 39 \\
\hline Corn silage & 37.3 & 34.0 & 31.0 & 27.9 \\
Alfalfa-grass silage & 14.5 & 11.1 & 5.88 & 0.55 \\
Wheat straw & - & 2.06 & 6.19 & 10.3 \\
Beet pulp & 6.22 & 6.19 & 6.19 & 6.19 \\
Concentrate mix & & & & \\
$\quad$ Distillers dried grains with solubles & 11.1 & 10.3 & 9.50 & 8.80 \\
Soybean meal, 48\% CP & 11.0 & 11.0 & 11.4 & 12.2 \\
Wheat middlings & 7.40 & 12.5 & 16.1 & 19.3 \\
Corn meal & 5.57 & 5.44 & 6.35 & 7.33 \\
Concentrate premix ${ }^{1}$ & 2.28 & 2.28 & 2.28 & 2.28 \\
Molasses & 1.74 & 1.92 & 1.82 & 1.68 \\
Calcium carbonate & 1.73 & 1.76 & 1.69 & 1.70 \\
Rumen inert fat $^{2}$ & 0.81 & 1.03 & 1.26 & 1.40 \\
Sodium chloride & 0.42 & 0.39 & 0.42 & 0.44 \\
\hline
\end{tabular}

${ }^{1}$ Contained 40.4\% AminoPlus (Ag Processing Inc., Omaha, NE), 31.6\% sodium bicarbonate, $12.3 \%$ urea, $0.9 \%$ Alimet (Novus International Inc., St. Louis, MO), 6.1\% magnesium oxide, 3.1\% selenium (contained $606 \mathrm{mg}$ of $\mathrm{Se} / \mathrm{kg}$ and $36.36 \% \mathrm{Ca}$ ), $2.6 \%$ potassium magnesium sulfate, $1.3 \%$ trace minerals (contained $0.02 \% \mathrm{Ca}, 18.82 . \%$ $\mathrm{S}, 153,709 \mathrm{mg}$ of $\mathrm{Zn} / \mathrm{kg}, 30,265 \mathrm{mg}$ of $\mathrm{Cu} / \mathrm{kg}, 142,610 \mathrm{mg}$ of $\mathrm{Mn} / \mathrm{kg}, 3,367 \mathrm{mg}$ of $\mathrm{Co} / \mathrm{kg}$, and 2,020 $\mathrm{mg}$ of I/ $\mathrm{kg}$ ), $1.3 \%$ (contained $30,678 \mathrm{kIU}$ of vitamin $\mathrm{A} / \mathrm{kg}, 5,868 \mathrm{kIU}$ of vitamin $\mathrm{D} / \mathrm{kg}$, and $93,997 \mathrm{IU}$ of vitamin $\mathrm{E} /$ $\mathrm{kg}$ ), and $0.4 \%$ organic trace minerals (contained $51,633 \mathrm{mg}$ of $\mathrm{Zn} / \mathrm{kg}, 17,959 \mathrm{mg}$ of $\mathrm{Cu} / \mathrm{kg}, 28,571 \mathrm{mg}$ of $\mathrm{Mn} /$ $\mathrm{kg}$, and $3,673 \mathrm{mg}$ of $\mathrm{Co} / \mathrm{kg}$ ).

${ }^{2}$ Cargill Inc. (Minneapolis, MN).

\section{Feed Analysis, Particle Size Distribution, and Physical Effectiveness Factor}

Individual feed ingredients were collected weekly and dried in a forced-air oven at $105^{\circ} \mathrm{C}$ for 18 to $24 \mathrm{~h}$ for DM determination to maintain dietary DM content throughout the duration of the study. Daily samples of individual feed ingredients, diets, and orts were collected during the collection period (d 13 to 19), and a portion of each sample (d 16 to 19) was dried in a forced-air oven at $105^{\circ} \mathrm{C}$ for 18 to $24 \mathrm{~h}$ for $\mathrm{DM}$ determination. The remaining portion was frozen at $-20^{\circ} \mathrm{C}$ until composited by period and analyzed for chemical composition using AOAC International (2000, 2006) approved methods (CPM Plus; Cumberland Valley Analytical Services Inc., Hagerstown, MD). In vitro NDF digestibility of diet composite samples (1-mm grind; Wiley mill, Arthur H. Thomas, Philadelphia, $\mathrm{PA})$ at 24-h was determined using an in vitro fermentation system (Daisy ${ }^{\text {II }}$ Incubator; Ankom Technology Corp., Fairport, NY) with buffered media containing ruminal fluid (Goering and Van Soest, 1970). Neutral detergent fiber with residual ash was determined by the Ankom A200 Fiber Analyzer filter bag technique (Ankom Technology Corp.; Van Soest et al., 1991) using $\alpha$-amylase but without sodium sulfite.

Forage and diet composite samples were used to determine particle size distribution (as-fed basis) using the Penn State Particle Separator (Lammers et al., 1996) and physical effectiveness factor ( pef $_{1.18}$; DM basis) by dry vertical sieving (Ro-Tap testing sieve shaker model B; W. S. Tyler Combustion Engineering Inc., Mentor, OH) using a 1.18-mm sieve (Mertens, 2002). The resultant pef $_{1.18}$ value was utilized to calculate peNDF $_{1.18}$ by multiplication of NDF content and pef $f_{1.18}$ value (Mertens, 1997). Fragility was calculated as the change in pef ${ }_{1.18}$ of dry, vertically sieved forage and diet composite samples before and after ball milling (5.5-L ceramic jar; Norton Chemical Process Products Division, Akron, OH; Cotanch et al., 2007; Cotanch and Grant, 2008).

\section{Measures of Chewing Activity and Rumen Dynamics}

Chewing Activity. Chewing activity (eating and ruminating) was monitored following the methods of Mitlöhner et al. (2001) modified to a 10-min scanning interval over a 48 -h period (from $0800 \mathrm{~h}$ on d 14 to 0800 $\mathrm{h}$ on d 16) by direct visual observation. Observations were not made while cows were located in the holding pen and milking parlor (approximately $90 \mathrm{~min} / \mathrm{d}$ ). Total time (min) spent on each activity for each day was quantified by multiplying the total number of observations for that activity by $10 \mathrm{~min}$.

Ruminal Fermentation. Ruminal $\mathrm{pH}$ was measured in 8 ruminally fistulated cows with an indwelling ruminal $\mathrm{pH} / \mathrm{ORP} / \mathrm{REDOX}$ measurement system (Penner et al., 2006; LRCpH; Dascor, Escondido, CA) at 30-s intervals over a 24-h period (from $0930 \mathrm{~h}$ on $\mathrm{d}$ 18 to $0930 \mathrm{~h}$ on d 19). Ruminal $\mathrm{pH}$ measurements were averaged over a 10-min period. Ruminal $\mathrm{pH}$ data were summarized as mean $\mathrm{pH}$, minimum $\mathrm{pH}$, maximum $\mathrm{pH}$, 


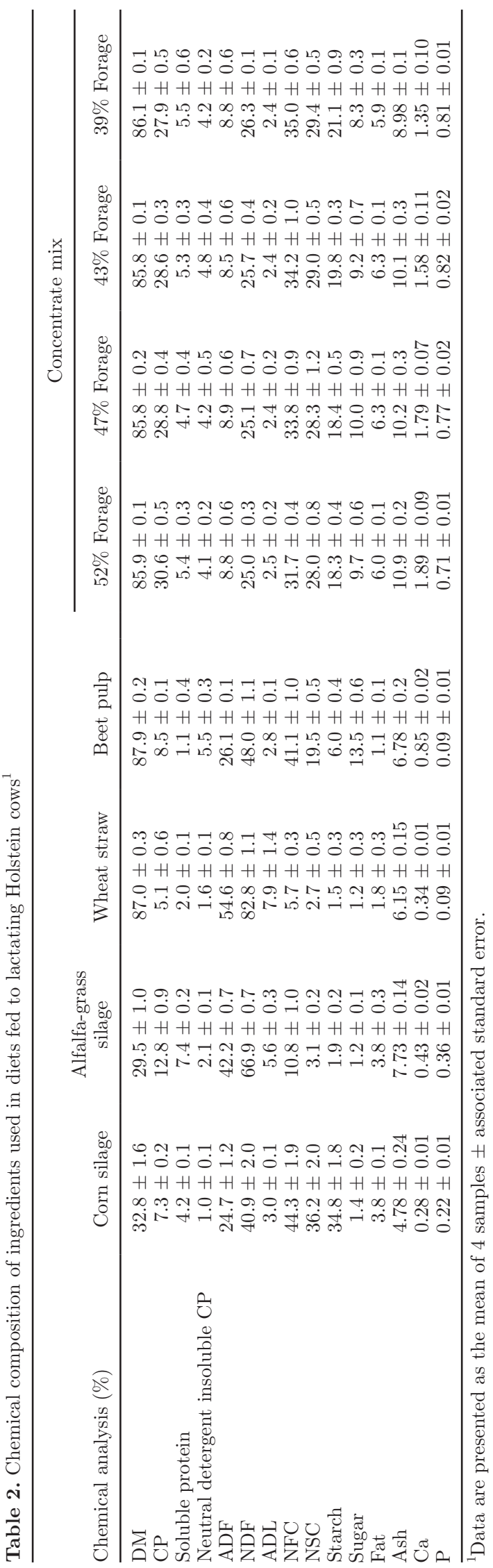

variation in $\mathrm{pH}$, and area that the $\mathrm{pH}$ curve was below pH of 5.8 (Bauer et al., 1995).

Samples of ruminal fluid $(250 \mathrm{~mL})$ were collected from beneath the ruminal digesta mat at 4-h intervals for 24 $\mathrm{h}$ on $\mathrm{d} 18(0930,1330,1730$, and $2130 \mathrm{~h})$ and $\mathrm{d} 19(0130$ and $0530 \mathrm{~h}$ ) of each period, and strained through 4 layers of cheesecloth; $\mathrm{pH}$ was determined immediately. An 80-mL aliquot of each rumen fluid sample was stored at $-20^{\circ} \mathrm{C}$ until VFA determination (Bulletin 856B; Supelco Inc., Bellefonte, PA) by gas chromatography with use of a Varian CP-3800 gas chromatograph (Varian Inc., Palo Alto, CA) equipped with a flame-ionization detector and a 80/120 Carbopack B-DA/4\% Carbowax 20M column (Supelco Inc.).

Ruminal Digesta Characteristics and Digestion Kinetics. Ruminal contents were evacuated manually through the ruminal cannula on d 20 (1430 $\mathrm{h}$ for multiparous cows; $1530 \mathrm{~h}$ for primiparous cows) and $\mathrm{d} 21$ (0530 $\mathrm{h}$ for primiparous cows; $0630 \mathrm{~h}$ for multiparous cows) for determination of ruminal content mass and volume. During evacuation, $10 \%$ of ruminal contents was subsampled and squeezed though a nylon screen (1-mm pore size) to separate solid and liquid phases. Each phase was weighed, and aliquots (300 g) from solid and liquid phases were then stored at $-20^{\circ} \mathrm{C}$ for further analysis. Solid and liquid phase samples were subsequently dried at $55^{\circ} \mathrm{C}$, ground (solids: $1-\mathrm{mm}$ screen; Wiley mill, Arthur H. Thomas; liquid: 1-mm screen, Udy Cyclone Sample Mill, Udy Corp., Fort Collins, $\mathrm{CO}$ ), and recombined based on DM proportion of each phase for analysis of ash (modified method 942.05; AOAC, 1990; $4 \mathrm{~h}$ at $600^{\circ} \mathrm{C}$ ), NDF (as described previously), and starch (Cumberland Valley Analytical Services Inc., Hagerstown, MD).

Ruminal pool size of OM, NDF, and starch was calculated as the product of ruminal content mass and nutrient content of ruminal contents. Ruminal turnover rate $(\% / \mathrm{h})$ of $\mathrm{OM}, \mathrm{NDF}$, and starch was calculated as [100 $\times$ (nutrient intake/ruminal pool of nutrient)/24] (Voelker Linton and Allen, 2008). Nutrient intake was calculated using DMI from d 20 and 21 and corresponding composite sample nutrient content. Ruminal turnover time $(\mathrm{h})$ was calculated as $1 /$ [ruminal turnover rate $(\% / \mathrm{h}) / 100]$.

Ruminal Mat Consistency. Ruminal mat consistency was measured approximately $3 \mathrm{~h}$ after feeding $(1330 \mathrm{~h})$ on d 20 following the methods of Welch (1982).

Microbial N Supply. Urinary excretion of purine derivatives (allantoin and uric acid) was used to estimate microbial N supply (Valadares et al., 1999) on d 18 and d 19 between 1400 and $1600 \mathrm{~h}$ using spot samples. A 40-mL urine sample was collected via manual stimulation of the vulva; a portion of urine was immediately diluted (1:10) with $0.036 \mathrm{~N} \mathrm{H}_{2} \mathrm{SO}_{4}$ and stored at $-20^{\circ} \mathrm{C}$ 
Table 3. Analyzed chemical composition and in vitro digestibility of diets fed to lactating Holstein cows ${ }^{1}$

\begin{tabular}{|c|c|c|c|c|}
\hline Chemical analysis (\%) & \multicolumn{4}{|c|}{ Forage in diet $(\%)$} \\
\hline DM & $44.7 \pm 1.0$ & $47.8 \pm 1.2$ & $52.6 \pm 1.2$ & $58.7 \pm 1.2$ \\
\hline $\mathrm{CP}$ & $17.3 \pm 0.2$ & $17.7 \pm 0.6$ & $17.3 \pm 0.3$ & $18.1 \pm 0.1$ \\
\hline Soluble protein & $5.12 \pm 0.6$ & $4.99 \pm 0.6$ & $4.48 \pm 0.5$ & $4.62 \pm 0.5$ \\
\hline NDIN & $3.1 \pm 0.3$ & $3.0 \pm 0.5$ & $2.8 \pm 0.2$ & $2.9 \pm 0.2$ \\
\hline ADL & $3.4 \pm 0.1$ & $3.2 \pm 0.2$ & $3.3 \pm 0.1$ & $3.4 \pm 0.1$ \\
\hline NFC & $36.2 \pm 0.4$ & $35.8 \pm 0.7$ & $36.0 \pm 0.8$ & $37.0 \pm 1.5$ \\
\hline NSC & $24.8 \pm 0.7$ & $25.6 \pm 0.4$ & $26.4 \pm 0.4$ & $26.8 \pm 1.1$ \\
\hline Starch & $20.2 \pm 0.6$ & $20.8 \pm 0.4$ & $21.2 \pm 0.2$ & $21.6 \pm 0.9$ \\
\hline Sugar & $4.6 \pm 0.2$ & $4.8 \pm 0.1$ & $5.1 \pm 0.3$ & $5.2 \pm 0.3$ \\
\hline Fat & $4.6 \pm 0.2$ & $4.5 \pm 0.1$ & $4.5 \pm 0.1$ & $4.5 \pm 0.1$ \\
\hline Ash & $7.68 \pm 0.2$ & $7.65 \pm 0.3$ & $7.90 \pm 0.4$ & $7.55 \pm 0.2$ \\
\hline
\end{tabular}

${ }^{1}$ Data are presented as the mean of 4 samples \pm associated standard error.

for later analysis of allantoin (Chen, 1989), and a 3-mL aliquot of urine was shipped with ice packs overnight to the Animal Diagnostic Center, Cornell University (Ithaca, NY) for analysis of creatinine (creatinine kit; Roche Diagnostics Corp., Indianapolis, IN) and uric acid (uric acid plus kit; Roche Diagnostics Corp.) with a chemistry analyzer (Hitachi 917; Roche Diagnostics Corp.).

\section{Total-Tract Nutrient Digestibility}

Total-tract digestibility of DM, OM, CP, ADF, NDF, cellulose, hemicellulose, and starch was determined on d 16 to 19 of each period. Fecal grab samples were collected on d 16 to 19 of each period so that every $3 \mathrm{~h}$ in a 24 -h period were represented. Fecal samples from each cow were composited by combining approximately $100 \mathrm{~g}$ of feces from each time point $(\mathrm{n}=8)$. Samples of diets and orts were collected at feeding on d 16 to 19 and immediately before feeding on d 17 to 20 . Samples of diets, orts, and feces were stored at $-20^{\circ} \mathrm{C}$, dried in a forced-air oven at $55^{\circ} \mathrm{C}$ for $48 \mathrm{~h}$, ground to pass through a 1-mm screen (Wiley mill, Arthur H. Thomas). Composite samples of diets (by period), orts (by cow within each period), and feces (by cow within each period) were analyzed for DM, CP, ADF, NDF, ash, lignin, and starch (Cumberland Valley Analytical Services Inc.). Indigestible NDF was used as an internal marker and its residue in diets, orts, and feces was quantified as NDF content of samples following an in vitro fermentation (Ankom Technology Corp.) in buffered rumen media (Goering and Van Soest, 1970) for 120 h. Totaltract digestibility was calculated by the ratio technique using the nutrient and indigestible NDF concentrations in the diet and feces (Maynard et al., 1979) adjusted for each cow based on the nutrient composition of the diet offered and refused.

\section{Statistical Analysis}

Ingredient and diet analyses were analyzed by descriptive statistics using the MEANS procedure of SAS (version 9.1; SAS Institute Inc., Cary, NC) and reported as the mean and standard error. Repeated measurements on performance, chewing, ruminal digesta characteristics and digestion kinetics, microbial nitrogen, and total-tract nutrient digestibility were reduced to period means for each cow before statistical analysis. All data, except for ruminal $\mathrm{pH}$ and VFA, were analyzed as a replicated Latin square design with model effects for diet, period, and replicate using the MIXED procedure of SAS with cow within replicate as a random effect. Ruminal $\mathrm{pH}$ and VFA were analyzed as a replicated Latin square design with repeated measures using the MIXED procedure of SAS. The model included the effects of diet, period, replicate, time, and the interaction of diet and time with cow within replicate as the random effect. Least squares means were separated using the Tukey procedure when a significant $F$-test $(P \leq 0.05)$ was detected.

\section{RESULTS}

\section{Feed Ingredients and Diet Composition}

As dietary forage content decreased from 52 to $39 \%$, corn silage decreased from 37.3 to $27.9 \%$, but haycrop silage decreased from 14.5 to $0.6 \%$ (Table 1 ). At the 
same time, chopped wheat straw increased from 0 to 10.3\% . All diets contained $6.2 \%$ beet pulp and a concentrate whose ingredient composition was adjusted to maintain similar carbohydrate and protein fractions (Tables 1, 2, and 3). Diets were similar in CP (average $17.6 \%$ ), NDIN (average 3.0\%), NDF (average 37.0\%), ADL (average $3.3 \%$ ), starch (average $20.9 \%$ ), and ether extract (average 4.5\%). As the forage content of the diet was reduced from 52 to $39 \%$, peNDF . $_{1.18}$ decreased from 21.5 to $18.9 \%$ (Table 4 ). Fragility of the wheat straw was much lower (29.2) than that of the corn silage (79.0) or haycrop silage (65.4).

\section{DMI and Lactation Performance}

As forage content in the diet decreased from 52 to $39 \%$, DMI increased $(P<0.03$; Table 5$)$. Decreasing dietary forage from 52 to $39 \%$ reduced $(P<0.01)$ $\mathrm{peNDF}_{1.18}$ intake from 4.86 to $4.58 \mathrm{~kg} / \mathrm{d}$, which reflected the lower DMI and peNDF ${ }_{1.18}$ content of the lower forage diets. However, reducing forage in these diets did not affect BW or change in BW over $19 \mathrm{~d}$, BCS or change in BCS over $19 \mathrm{~d}$, milk yield, or milk composition. Lower dietary forage increased $(P<0.01)$ MUN concentration from 15.5 to $18.4 \mathrm{mg} / \mathrm{dL}$ with no effect on SCS.

\section{Chewing Activity}

Reducing forage in the diet did not affect total time spent chewing or eating when expressed as minutes per day or as minutes per kilogram of NDF intake (Table 6). However, reducing dietary forage increased $(P<0.01)$ chewing time per kilogram of peNDF ${ }_{1.18}$ intake. Similar to total chewing time, reducing forage in the diet did not affect total time eating (minutes per day or minutes per kilogram of NDF intake; Table 6$)$ and increased $(P$ $<0.01$ ) eating time per kilogram of peNDF $_{1.18}$ intake. In contrast to eating and total chewing time, decreasing forage in the diet did not affect total time spent ruminating (in minutes per day, minutes per kilogram of NDF intake, or minutes per kilogram of intake; Table $6)$.

\section{Ruminal pH, Fermentation, Digesta Characteristics, Turnover, and Digesta Mat Consistency}

Reducing dietary forage did not influence mean $\mathrm{pH}$, area under a $\mathrm{pH}$ of 5.8, minimum and maximum $\mathrm{pH}$, or range in $\mathrm{pH}$ (Table 7 ). Reducing the percentage of forage in the diet tended to increase $(P=0.06)$ VFA concentration although the range among diets was small (127 to $136 \mathrm{mM}$ ). Decreasing percentage of dietary forage did not affect acetate, butyrate, valerate, or isovalerate concentrations, but lower forage increased $(P<0.01)$ propionate and isobutyrate concentrations. Lower dietary forage reduced $(P<0.01)$ the ratio of acetate to propionate and the ratio of the sum of acetate and butyrate to propionate. Despite these changes in VFA ratios, decreasing dietary forage percentage did not influence microbial $\mathrm{N}$ yield (Table 7 ).

Decreasing the percentage of forage in the diet did not influence ruminal digesta volume, mass, or density (Table 8). Additionally, we did not detect differences among diets in ruminal pool size of OM, NDF, or starch. Reducing dietary forage increased $(P<0.01)$ ruminal turnover rate $(\% / \mathrm{h})$ of $\mathrm{OM}$ and reduced $(P<0.02)$ the ruminal turnover time (h). Similarly, as dietary forage content was reduced, the turnover rate of NDF $(P<0.03)$ and starch $(P<0.01)$ increased. Reducing the percentage of forage in the diet from 52 to $39 \%$ did not alter ruminal mat consistency as measured by distance traveled and the rate at which a weight traveled through the digesta mat (data not shown), which may have reflected a positive effect of added straw on maintaining mat consistency.

\section{Total-Tract Nutrient Digestibility}

Reducing the percentage of forage in diets decreased $(P<0.01)$ total-tract digestibility of $\mathrm{DM}$ and $\mathrm{OM}$ (Table 9). Decreasing dietary forage reduced $(P<$ 0.01 ) total-tract digestibility of ADF, NDF, cellulose, and hemicellulose. In contrast, total-tract digestibility of starch was not influenced by the reduction in dietary forage content.

\section{DISCUSSION}

In our study, dietary forage content was reduced from 52 to $39 \%$ by feeding less corn silage and haycrop silage and increasing the amount of straw and concentrate that contained NFFS in place of corn grain. Dietary peNDF ${ }_{1.18}$ was reduced from 21.5 to $18.9 \%$ of DM. Similar reductions in dietary forage content and associated decreases in peNDF$_{1.18}$ have resulted in reduced chewing activity by the cow (Mertens, 1997). In an effort to avoid this expected reduction in chewing activity as forage content declined, we added chopped wheat straw incrementally to the diets (from 0 to $10 \%$ of dietary DM) as silage content was reduced from 51.8 to $28.5 \%$. Mertens (1997) reported that straw elicited approximately 1.74 times the chewing response of alfalfa or grass forage of similar long particle size. In our study, chewing activity was maintained by wheat straw addition as forage content and dietary peNDF ${ }_{1.18}$ were reduced because the straw stimulated greater chewing per kilogram of peNDF 1.18 consumed. Associated with 
Table 4. Particle size distribution, physical effectiveness factor ( pef $_{1.18}$ ), and physically effective neutral detergent fiber ( peNDF $_{1.18}$ ) of forage ingredients and diets fed to lactating Holstein cows

Item

Forage ingredient

Forage in $\operatorname{diet}(\%)$

Item

Particle size distribution (\% as fed)

$>19.0 \mathrm{~mm}$

$8.0-19.0 \mathrm{~mm}$

$<8.0 \mathrm{~mm}$

Particle size distribution (\% of DM)

$>19.00 \mathrm{~mm}$

$13.20-19.00 \mathrm{~mm}$

$9.50-13.20 \mathrm{~mm}$

$6.70-9.50 \mathrm{~mm}$

$4.75-6.70 \mathrm{~mm}$

$3.35-4.75 \mathrm{~mm}$

2.36- $3.35 \mathrm{~mm}$

1.18-2.36 mm

$0.60-1.18 \mathrm{~mm}$

$<0.30 \mathrm{~mm}$

$<0.30$
$\operatorname{pef}_{1.18}$

peNDF $_{1.18}{ }^{3}(\%)$

Fragility ${ }^{4}(\%)$

Alfalfa-gras
corn silage

Wheat straw

52

47

43

39

$4.50 \pm 0.7$

\section{$9.40 \pm 1.4$}

$23.9 \pm 3.6$

$74.6 \pm 1.9$
$20.9 \pm 2.5$

$29.9 \pm 0.6$

$38.5 \pm 2.1$

$2.20 \pm 0.3$

$3.00 \pm 0.3$

$38.9 \pm 1.4$

$58.2 \pm 1.6$

$3.20 \pm 0.6$

$32.7 \pm 2.9$

$55.2 \pm 1.5$

$0.0 \pm 0.0$

$0.0 \pm 0.0$
$0.2 \pm 0.1$

$0.2 \pm 0.1$

$0.1 \pm 0.0$

$0.3 \pm 0.1$

$0.6 \pm 0.1$

$3.2 \pm 0.2$

$0.1 \pm 0.0$

$0.2 \pm 0.0$
$0.5 \pm 0.0$

$0.5 \pm 0.0$

$12.9 \pm 1.2$

$14.2 \pm 1.6$

$1.0 \pm 0.1$

$1.4 \pm 0.2$

$2.5 \pm 0.2$

$1.5 \pm 0.1$

$13.4 \pm 1.4$
$9.8 \pm 1.2$

$4.5 \pm 0.2$

$3.8 \pm 0.1$

$5.2 \pm 0.3$

$9.0 \pm 0.7$

$\begin{array}{rr}9.2 \pm 1.1 & 12.3 \pm 0.9 \\ 3.4 \pm 0.4 & 8.6 \pm 0.5 \\ 1.6 \pm 0.2 & 2.6 \pm 0.1\end{array}$

$1.6 \pm 0.2 \quad 2.6 \pm 0.1$

$\begin{array}{ll}1.6 \pm 0.2 & 2.6 \pm 0.1 \\ 1.0 \pm 0.1 & 0.7 \pm 0.0\end{array}$

$1.0 \pm 0.1$

$0.92 \pm 0.01$

$36.8 \pm 1.6$
$79.0 \pm 1.3$

$\begin{array}{ll}3.0 \pm 0.3 \\ 0.7 \pm 0.0 & 1.0 \pm 0.3\end{array}$

$0.64 \pm 0.02 \quad 0.5 \pm 0.2$

$0.82 \pm 0.03$

$65.4 \pm 4.0$

$29.2 \pm 2.9$

$\begin{array}{cccc}0.1 \pm 0.1 & 0.0 \pm 0.0 & 0.1 \pm 0.0 & 0.1 \pm 0.0 \\ 0.5 \pm 0.1 & 0.3 \pm 0.1 & 0.2 \pm 0.0 & 0.2 \pm 0.0 \\ 1.9 \pm 0.2 & 1.6 \pm 0.1 & 1.4 \pm 0.2 & 1.7 \pm 0.5 \\ 8.3 \pm 0.9 & 6.8 \pm 0.7 & 5.7 \pm 0.4 & 6.1 \pm 0.6 \\ 7.2 \pm 0.3 & 6.8 \pm 0.6 & 5.8 \pm 0.2 & 5.5 \pm 0.6 \\ 7.9 \pm 0.5 & 7.6 \pm 0.7 & 6.7 \pm 0.5 & 6.7 \pm 0.6 \\ 6.9 \pm 0.5 & 6.7 \pm 0.6 & 6.5 \pm 0.6 & 6.5 \pm 0.7 \\ 19.8 \pm 1.6 & 20.3 \pm 2.0 & 19.7 \pm 2.2 & 21.8 \pm 2.9 \\ 25.1 \pm 1.9 & 27.5 \pm 1.9 & 25.7 \pm 2.3 & 26.9 \pm 3.3 \\ 10.0 \pm 0.7 & 12.0 \pm 1.2 & 12.6 \pm 1.8 & 13.9 \pm 2.0 \\ 2.5 \pm 0.2 & 2.7 \pm 0.3 & 3.1 \pm 0.5 & 3.8 \pm 0.6 \\ 0.59 \pm 0.01 & 0.54 \pm 0.01 & 0.53 \pm 0.02 & 0.53 \pm 0.02 \\ 21.5 \pm 0.5 & 20.2 \pm 0.6 & 19.2 \pm 0.9 & 18.9 \pm 0.7 \\ 86.5 \pm 4.6 & 88.5 \pm 2.2 & 82.6 \pm 5.5 & 85.8 \pm 1.5\end{array}$

Data are presented as the mean of 4 samples \pm associated standard error.

${ }^{2}$ Physical effectiveness factor as determined using the methods of Mertens (2002).

${ }^{3}$ Physically effective neutral detergent fiber as determined using the methods of Mertens (1997).

${ }^{4}$ Measured as the change in $\operatorname{pef}_{1.18} ;\left(\operatorname{pef}_{1.18 \text { initial }}-\operatorname{pef}_{1.18 \text { ball milling }}\right) / \operatorname{pef}_{1.18 \text { initial }} \times 100$. 
Table 5. Performance data of lactating Holstein cows fed low-starch diets varying in forage content

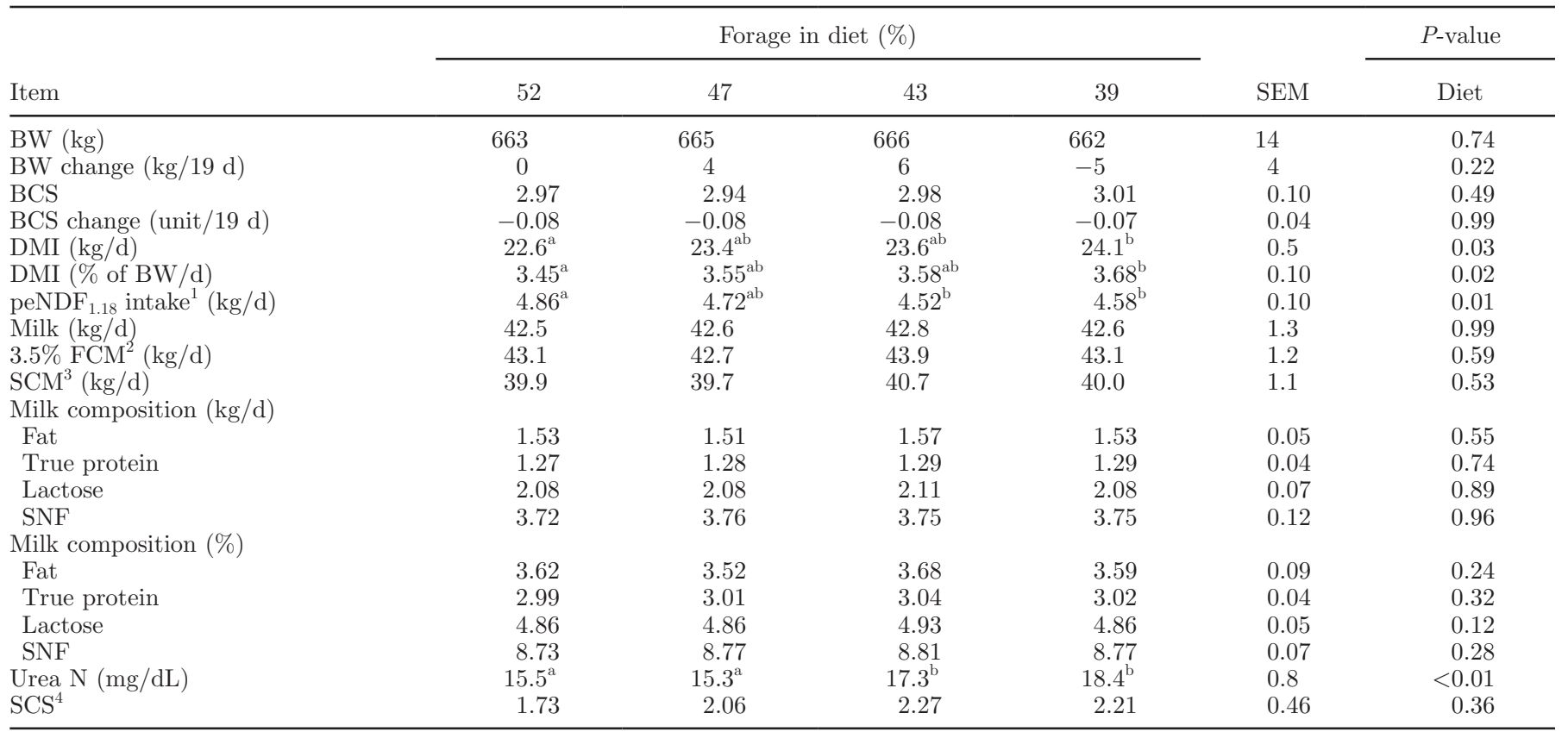

${ }^{\mathrm{a}, \mathrm{b}}$ Least squares means within a row without a common superscript differ $(P \leq 0.05)$.

${ }^{1}$ Physically effective neutral detergent fiber as determined using the methods of Mertens (1997).

${ }^{2} 3.5 \% \mathrm{FCM}(\mathrm{kg})=(0.4324 \times \mathrm{kg}$ of milk $)+(16.216 \times \mathrm{kg}$ of fat $)$.

${ }^{3} \mathrm{SCM}$ containing $748 \mathrm{kcal} / \mathrm{kg} ; \mathrm{SCM}(\mathrm{kg})=(12.3 \times \mathrm{kg}$ of fat $)+(6.56 \times \mathrm{kg}$ of SNF $)-(0.0752 \times \mathrm{kg}$ of milk $)$.

${ }^{4} \mathrm{SCS}=\left\{\left[\log _{10}(\mathrm{SCC} \div 1,000)-2\right] \div \log _{10}(2)\right\}+3$.

this maintenance of chewing activity, we observed no effect of lower dietary forage on milk yield, milk composition, or any measure of ruminal $\mathrm{pH}$.

Eating activity, when expressed as a function of $\mathrm{peNDF}_{1.18}$ intake, was greater for cows fed $39 \%$ versus $52 \%$ forage, whereas rumination activity was not affected. Previous research has observed similar patterns of total eating activity and therefore chewing time being influenced by forage level and dietary peNDF ${ }_{1.18}$ while rumination remained relatively unaffected (Beauche- min and Yang, 2005; Yang and Beauchemin, 2009; Lechartier and Peyraud, 2010). These data suggest that eating rather than ruminating may be more responsive to differences in dietary physical form.

It is known that NDF from NFFS is not as effective at stimulating chewing as NDF from forage sources (Grant, 1997; Pereira et al., 1999; Pereira and Armentano, 2000). In our study, substitution of corn starch with digestible fiber from NFFS (beet pulp, distillers grains, and wheat middlings) resulted in a relatively

Table 6. Chewing activity data of lactating Holstein cows fed low-starch diets varying in forage content

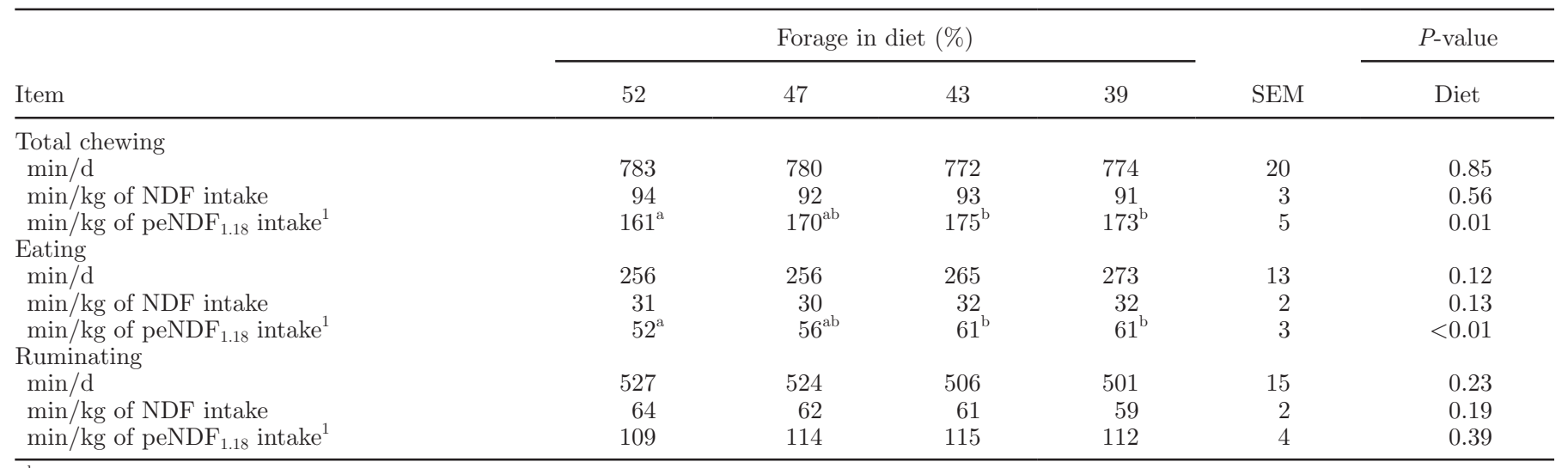

${ }^{\mathrm{a}, \mathrm{b}}$ Least squares means within a row without a common superscript differ $(P \leq 0.05)$.

${ }^{1}$ Physically effective neutral detergent fiber as determined using the methods of Mertens (1997). 
Table 7. Rumen characteristics of lactating cows fed low-starch diets varying in forage content

\begin{tabular}{|c|c|c|c|c|c|c|}
\hline Item & \multicolumn{4}{|c|}{ Forage in diet $(\%)$} & SEM & $\frac{P \text {-value }}{\text { Diet }}$ \\
\hline Ruminal pH & 6.06 & 6.02 & 6.06 & 6.13 & 0.07 & 0.15 \\
\hline Minimum pH & 5.59 & 5.49 & 5.54 & 5.61 & 0.11 & 0.62 \\
\hline Maximum $\mathrm{pH}$ & 6.64 & 6.60 & 6.62 & 6.65 & 0.06 & 0.90 \\
\hline Range in pH & 1.06 & 1.11 & 1.09 & 1.03 & 0.09 & 0.86 \\
\hline Propionate $(\mathrm{P})$ & $29.9^{\mathrm{a}}$ & $33.8^{\mathrm{b}}$ & $32.5^{\mathrm{ab}}$ & $35.1^{\mathrm{b}}$ & 1.9 & $<0.01$ \\
\hline Butyrate (B) & 15.0 & 16.2 & 15.5 & 16.3 & 0.6 & 0.15 \\
\hline Isobutyrate & $0.89^{\mathrm{a}}$ & $0.93^{\mathrm{a}}$ & $0.96^{\mathrm{ab}}$ & $1.04^{\mathrm{b}}$ & 0.04 & $<0.01$ \\
\hline Valerate & 2.58 & 2.70 & 3.13 & 3.21 & 0.33 & 0.18 \\
\hline Isovalerate & 1.27 & 1.25 & 1.35 & 1.45 & 0.16 & 0.41 \\
\hline $\mathrm{A}: \mathrm{P}$ & $2.68^{\mathrm{a}}$ & $2.47^{\mathrm{bc}}$ & $2.48^{\mathrm{b}}$ & $2.30^{\mathrm{c}}$ & 0.14 & $<0.01$ \\
\hline
\end{tabular}

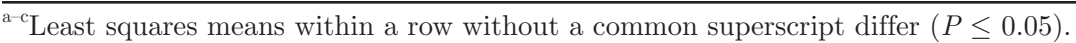

${ }^{\mathrm{x}, \mathrm{y}}$ Least squares means within a row without a common superscript tend to differ $(0.5<P \leq 0.1)$.

low dietary starch content of $20.9 \%$. Previous studies have demonstrated that replacement of starch with digestible fiber from NFFS results in higher ruminal $\mathrm{pH}$ and greater production of SCM (Pereira et al., 1999; Voelker and Allen, 2003). It is likely that the beneficial influence of NFFS on ruminal fermentation helped to explain the maintenance of milk and milk components as forage content was reduced. Overall, the productive and ruminal $\mathrm{pH}$ responses reflect the effects of NFFS.

Reducing dietary silage content and increasing the contribution of straw to total dietary NDF lowered total tract $\mathrm{OM}$ and fiber digestibility. Because lignin content was similar (average $3.0 \%$ ) for all diets, it is likely that differences in lignin cross-linking with cell wall components among the silages, the straw, and the
NFFS partly explain this digestibility response (Dann et al., 2006). Although the majority of NFFS feedstuffs are relatively digestible when compared with forage fiber, digestibility of NFFS in vivo may be limited by a rapid passage rate (Edionwe and Owen, 1989; Bhatti and Firkins, 1995; Firkins, 1997; Dann et al., 2007). Moreover, the observed decrease in overall DM and OM digestibility coupled with a more rapid rumen OM turnover rate may have resulted in lower availability of carbohydrate to the rumen microbes and the cow per kilogram of feed for the lower forage diets (Kendall et al., 2009).

In the current study, ruminal acetate concentration was unaffected by diet, whereas propionate and isobutyrate concentrations increased with decreasing

Table 8. Ruminal digesta characteristics and digestion kinetics of lactating Holstein cows fed low-starch diets varying in forage content

\begin{tabular}{|c|c|c|c|c|c|c|}
\hline \multirow[b]{2}{*}{ Item } & \multicolumn{4}{|c|}{ Forage in diet $(\%)$} & \multirow[b]{2}{*}{ SEM } & \multirow{2}{*}{$\frac{P \text {-value }}{\text { Diet }}$} \\
\hline & 52 & 47 & 43 & 39 & & \\
\hline Ruminal density $(\mathrm{kg} / \mathrm{L})$ & 0.89 & 0.86 & 0.86 & 0.87 & 0.02 & 0.71 \\
\hline \multicolumn{7}{|l|}{ Ruminal pool (kg) } \\
\hline $\mathrm{OM}$ & 12.3 & 12.3 & 12.0 & 12.1 & 1.1 & 0.95 \\
\hline \multicolumn{7}{|l|}{ Ruminal turnover rate $(\% / \mathrm{h})$} \\
\hline $\mathrm{OM}$ & $6.98^{\mathrm{a}}$ & $7.46^{\mathrm{ab}}$ & $8.06^{\mathrm{b}}$ & $8.02^{\mathrm{b}}$ & 0.51 & 0.01 \\
\hline $\mathrm{NDF}$ & $3.98^{\mathrm{a}}$ & $4.36^{\mathrm{ab}}$ & $4.55^{\mathrm{b}}$ & $4.48^{\mathrm{ab}}$ & 0.30 & 0.03 \\
\hline Starch & $69.6^{\mathrm{a}}$ & $95.5^{\mathrm{b}}$ & $99.4^{\mathrm{b}}$ & $92.6^{\mathrm{b}}$ & 7.2 & 0.01 \\
\hline \multicolumn{7}{|l|}{ Ruminal turnover time $(\mathrm{h})$} \\
\hline OM & $14.7^{\mathrm{a}}$ & $14.1^{\mathrm{ab}}$ & $12.8^{\mathrm{b}}$ & $13.1^{\mathrm{ab}}$ & 1.0 & 0.02 \\
\hline $\mathrm{NDF}$ & 25.6 & 24.2 & 22.9 & 23.5 & 1.8 & 0.07 \\
\hline
\end{tabular}

\footnotetext{
${ }^{\mathrm{a}, \mathrm{b}}$ Least squares means within a row without a common superscript differ $(P \leq 0.05)$.
} 
Table 9. Total-tract nutrient digestibility of lactating Holstein cows fed low-starch diets varying in forage content

\begin{tabular}{lccccccr}
\hline & \multicolumn{5}{c}{ Forage in diet $(\%)$} & & \multicolumn{2}{c}{$P$-value } \\
\cline { 2 - 5 } Item & 52 & 47 & 43 & 39 & SEM & Diet \\
\hline DM (\%) & $62.2^{\mathrm{a}}$ & $60.9^{\mathrm{ab}}$ & $59.8^{\mathrm{bc}}$ & $58.6^{\mathrm{c}}$ & 0.7 & $<0.01$ \\
OM (\%) & $64.5^{\mathrm{a}}$ & $63.3^{\mathrm{ab}}$ & $62.0^{\mathrm{bc}}$ & $61.0^{\mathrm{c}}$ & 0.7 & $<0.01$ \\
CP (\%) & $67.7^{\mathrm{a}}$ & 67.8 & 66.1 & 67.9 & 0.7 & 0.09 \\
ADF (\%) & $34.1^{\mathrm{a}}$ & $31.4^{\mathrm{ab}}$ & $28.5^{\mathrm{b}}$ & $23.1^{\mathrm{c}}$ & 1.3 & $<0.01$ \\
NDF (\%) & $39.4^{\mathrm{a}}$ & $35.9^{\mathrm{ab}}$ & $34.0^{\mathrm{b}}$ & $29.1^{\mathrm{c}}$ & 1.3 & $<0.01$ \\
Cellulose (\%) & $39.2^{\mathrm{a}}$ & $37.4^{\mathrm{a}}$ & $34.7^{\mathrm{a}}$ & $28.7^{\mathrm{b}}$ & 1.3 & $<0.01$ \\
Hemicellulose (\%) & $45.4^{\mathrm{a}}$ & $41.0^{\mathrm{ab}}$ & $40.3^{\mathrm{bc}}$ & $35.4^{\mathrm{c}}$ & 1.6 & $<0.01$ \\
Starch (\%) & 97.1 & 97.3 & 97.4 & 97.3 & 0.2 & 0.69 \\
\hline
\end{tabular}

${ }^{\mathrm{a}-\mathrm{c}}$ Least squares means within a row without a common superscript differ $(P \leq 0.05)$.

forage content, lower peNDF ${ }_{1.18}$, and greater NFFS inclusion. Total VFA as well as acetate concentrations were unchanged across rations, possibly suggesting equivalence of fermentable fiber as NFFS replaces forage from corn silage and haycrop silage. Furthermore, increased propionate indicates increased ruminal degradation of starch, as the ruminal starch pool did not differ. Previous research has resulted in variable responses in ruminal VFA concentrations to inclusion of NFFS and altered forage content. In some studies, acetate concentrations were increased and propionate concentrations decreased when inclusion of NFFS increased (Ipharraguerre et al., 2002; Voelker and Allen, 2003). Conversely, when the forage-to-concentrate ratio was reduced, acetate and isobutyrate concentrations were reduced and propionate concentrations increased (Lechartier and Peyraud, 2010). Altered patterns in VFA profile suggest differing availability and use of carbohydrates by ruminal microorganisms in response to altered dietary nutrient concentrations (Broderick et al., 2008). In our study, in the absence of any alterations in ruminal mass, volume, digesta mat consistency, or microbial $\mathrm{N}$ yield via urine, it appears that normal ruminal function and substrate utilization were maintained on the lower starch, lower forage diets compared with the higher forage diet.

The lower forage diets were associated with greater DMI, with cows fed the $39 \%$ forage diet consuming $6.6 \%$ more DMI than the $52 \%$ forage diet. This increase in DMI as forage content was reduced reflects the greater turnover of OM, NDF, and starch observed as forage content declined. Despite the changes in DMI, the economics of feeding a lower starch, lower forage diet, as well as the need to reduce forage use due to limited supply, may drive use of a similar diet under specific conditions. Previous research has shown that a $20 \%$ starch diet with NFFS inclusion decreased cost per cow per day by $29 \%$ compared with a $29 \%$ starch diet without NFFS inclusion (Ranathunga et al., 2010).
Additionally, a high NFFS diet reduced feed costs by $\$ 0.31 /$ cow per day compared with a traditional corn silage and alfalfa lactation diet (Rezac et al., 2010). It should be noted that the economics of replacing forage with NFFS must be considered on an individual basis, considering the regional supply and cost of forages relative to supply and cost of NFFS and grains.

\section{CONCLUSIONS}

With the use of wheat straw and NFFS, the forage content of the study diets could be reduced from 52 to $39 \%$ of dietary DM. As forage content was lowered, the added wheat straw successfully maintained total chewing activity. Ruminal $\mathrm{pH}$ and microbial $\mathrm{N}$ production were maintained as forage content was reduced for these lower starch diets. Reductions in total-tract OM digestibility were related to greater ruminal turnover of NDF and starch as dietary forage content was reduced. These short-term studies indicate that the lower forage diets were associated with greater DMI, with cows fed the $39 \%$ forage diet consuming $6.6 \%$ more DMI than the $52 \%$ forage diet. Despite the changes in DMI, SCM production was unaffected by diet, which resulted in a decrease in feed utilization for milk production between the 52 and $39 \%$ forage diets. Lower forage diets with lower starch content represent a viable strategy for feeding high-producing dairy cows under conditions of expensive or limited supplies of corn-based grain and high-quality forages.

\section{ACKNOWLEDGMENTS}

This work was supported in part by a grant from ZEN-NOH National Federation of Agricultural Cooperative Associations (Tokyo, Japan). Graduate assistantship support for E. R. Farmer was provided by the University of Vermont (Burlington). The authors are grateful to the Miner Institute dairy farm staff, S. 
E. Boucher, R. E. Butzler, M. P. Carter, R. E. Clark, R. T. Fievisohn, H. M. Gauthier, L. B. Klaiber, and C. L. Preseault, for their assistance with this study.

\section{REFERENCES}

Allen, M. S. 2000. Effects of diet on short-term regulation of feed intake by lactating dairy cattle. J. Dairy Sci. 83:1598-1624.

AOAC. 1990. Official Methods of Analysis. 15th ed. Association of Official Analytical Chemists (AOAC), Arlington, VA.

AOAC International. 2000. Official Methods of Analysis. 17th ed. AOAC International, Arlington, VA.

AOAC International. 2006. Official Methods of Analysis. 18th ed. AOAC International, Arlington, VA.

Bauer, M. L., D. W. Herold, R. A. Britton, R. A. Stock, T. J. Klopfenstein, and D. A. Yates. 1995. Efficacy of laidlomycin propionate to reduce ruminal acidosis in cattle. J. Anim. Sci. 73:3445-3454.

Beauchemin, K. A., and W. Z. Yang. 2005. Effects of physically effective fiber on intake, chewing activity, and ruminal acidosis for dairy cows fed diets based on corn silage. J. Dairy Sci. 88:2117-2129.

Bhatti, S. A., and J. L. Firkins. 1995. Kinetics of hydration and functional specific gravity of fibrous feed by-products. J. Anim. Sci. 73:1449-1458

Bradford, B. J., and C. R. Mullins. 2012. Strategies for promoting productivity and health of dairy cattle by feeding nonforage fiber sources. J. Dairy Sci. 95:4735-4746.

Broderick, G. A., N. D. Luchini, S. M. Reynal, G. A. Varga, and V. A. Ishler. 2008. Effect of production on replacing dietary starch with sucrose in lactating dairy cows. J. Dairy Sci. 91:4801-4810.

Chen, X. B. 1989. Excretion of purine derivatives by sheep and cattle and its use for the estimation of absorbed microbial protein. $\mathrm{PhD}$ Diss. University of Aberdeen, Aberdeen, United Kingdom.

Cotanch, K. W., and R. J. Grant. 2008. Fiber digestibility and forage fragility in dairy cattle. Pages 77-83 in Proc. Cornell Nutr. Conf. Feed Manuf., East Syracuse, NY. Cornell University, Ithaca, NY.

Cotanch, K. W., R. J. Grant, J. Darrah, H. M. Wolford, and T. Eguchi. 2007. Development of a method for measuring forage fragility. J. Dairy Sci. 90(Suppl. 1):563-564. (Abstr.)

Dann, H. M., M. P. Carter, K. W. Cotanch, C. S. Ballard, T. Takano, and R. J. Grant. 2007. Effect of partial replacement of forage neutral detergent fiber with by-product neutral detergent fiber in close-up diets on periparturient performance of dairy cow. J. Dairy Sci. 90:1789-1801.

Dann, H. M., K. W. Cotanch, P. D. Krawczel, C. S. Mooney, R. J. Grant, and T. Eguchi. 2008. Evaluation of low starch diets for lactating Holstein dairy cattle. J. Dairy Sci. 91(E-Suppl. 1):530. (Abstr.)

Dann, H. M., R. J. Grant, M. E. Van Amburgh, and P. J. V. Soest. 2006. Lignin-carbohydrate linkages, lignin, and the relationship with fiber digestibility. Pages 87-98 in Proc. Cornell Nutr. Conf. for Feed Manuf., Syracuse, NY. Cornell University, Ithaca, NY.

Edionwe, A. O., and F. G. Owen. 1989. Relation of intake to digestibility of diets containing soyhulls and distillers dried grains. J. Dairy Sci. 72:1786-1792.

Ferguson, J. D., D. T. Galligan, and N. Thomsen. 1994. Principal descriptors of body condition score in Holstein cows. J. Dairy Sci. 77:2695-2703.

Firkins, J. L. 1997. Effects of feeding nonforage fiber sources on site of fiber digestion. J. Dairy Sci. 80:1426-1437.

Gencoglu, H., R. D. Shaver, W. Steinberg, J. Ensink, L. F. Ferraretto, S. J. Bertics, J. C. Lopes, and M. S. Akins. 2010. Effect of feeding a reduced-starch diet with or without amylase addition on lactation performance in dairy cows. J. Dairy Sci. 93:723-732.

Goering, H. K., and P. J. Van Soest. 1970. Forage Fiber Analysis (Apparatus, Reagents, Procedures, and Some Applications). Agriculture Handbook No. 379. USDA Agricultural Research Service, Washington, DC

Grant, R. J. 1997. Interactions among forages and nonforage fiber sources. J. Dairy Sci. 80:1438-1446.
Ipharraguerre, I. R., Z. Shabi, J. H. Clark, and D. E. Freeman. 2002 Ruminal fermentation and nutrient digestibility by dairy cows fed varying amounts of soyhulls as a replacement for corn grain. J. Dairy Sci. 85:2890-2904.

Kendall, C., C. Leonardi, P. C. Hoffman, and D. K. Combs. 2009. Intake and milk production of cows fed diets that differed in dietary neutral detergent fiber and neutral detergent fiber digestibility. J. Dairy Sci. 92:313-323.

Kononoff, P. J., S. K. Ivan, W. Matzke, R. J. Grant, R. A. Stock, and T. J. Klopfenstein. 2006. Milk production of dairy cows fed wet corn gluten feed during the dry period and lactation. J. Dairy Sci. 89:2608-2617.

Lammers, B. P., D. R. Buckmaster, and A. J. Heinrichs. 1996. A simple method for the analysis of particle sizes of forage and total mixed rations. J. Dairy Sci. 79:922-928.

Lechartier, C., and J. L. Peyraud. 2010. The effects of forage proportion and rapidly degradable dry matter from concentrate on ruminal digestion in dairy cows fed corn silage-based diets with fixed neutral detergent fiber and starch contents. J. Dairy Sci. 93:666-681.

Maynard, L. A., J. K. Loosli, H. F. Hintz, and R. G. Warner. 1979. Digestive processes in different species. Pages 21-46 in Animal Nutrition. McGraw-Hill Inc., New York, NY.

Mertens, D. R. 1997. Creating a system for meeting the fiber requirements of dairy cows. J. Dairy Sci. 80:1463-1481.

Mertens, D. R. 2002. Determination of starch in large particles. RoTap shaker method. Revised April 2002. US Dairy Forage Research Center, Madison, WI.

Mitlöhner, F. M., J. L. Morrow-Tesch, S. C. Wilson, J. W. Dailey, and J. J. McGlone. 2001. Behavioral sampling techniques for feedlot cattle. J. Anim. Sci. 79:1189-1193.

Penner, G. B., K. A. Beauchemin, and T. Mutsvangwa. 2006. An evaluation of the accuracy and precision of a stand-alone submersible continuous ruminal $\mathrm{pH}$ measurement system. J. Dairy Sci. $89: 2132-2140$

Pereira, M. N., and L. E. Armentano. 2000. Partial replacement of forage with nonforage fiber sources in lactating cow diets. II. Digestion and rumen function. J. Dairy Sci. 83:2876-2887.

Pereira, M. N., E. F. Garrett, G. R. Oetzel, and L. E. Armentano. 1999. Partial replacement of forage with nonforage fiber sources in lactating cow diets. I. Performance and health. J. Dairy Sci. $82: 2716-2730$.

Plaizier, J. C., D. O. Krause, G. N. Gozho, and B. W. McBride. 2008 Subacute ruminal acidosis in dairy cows: The physiological causes, incidence and consequences. Vet. J. 176:21-31.

Ranathunga, S. D., K. F. Kalscheur, A. R. Hippen, and D. J. Schingoethe. 2010. Replacement of starch from corn with nonforage fiber from distillers grains and soyhulls in diets of lactating cows. J. Dairy Sci. 93:1086-1097.

Rezac, D. J., K. N. Grisby, and B. J. Bradford. 2010. Effects of varying rates of tallgrass prairie hay and wet corn gluten feed on productivity of dairy cows. Kansas State University Dairy Research 2010. Accessed Apr. 15, 2013. http://www.ksre.ksu.edu/library/lvstk2/ srp1039.pdf

Valadares, R. F. D., G. A. Broderick, S. C. Valadares Filho, and M. K. Clayton. 1999. Effect of replacing alfalfa silage with high moisture corn on ruminal protein synthesis estimated from excretion of total purine derivatives. J. Dairy Sci. 82:2686-2696.

Van Soest, P. J., J. B. Robertson, and B. A. Lewis. 1991. Methods for dietary fiber, neutral detergent fiber, and nonstarch polysaccharides in relation to animal nutrition. J. Dairy Sci. 74:3583-3597.

Voelker, J. A., and M. S. Allen. 2003. Pelleted beet pulp substituted for high-moisture corn: 1. Effects on feed intake, chewing behavior, and milk production of lactating cows. J. Dairy Sci. 86:3542-3552.

Voelker Linton, J. A., and M. S. Allen. 2008. Nutrient demand interacts with forage family to affect intake and digestion responses in dairy cows. J. Dairy Sci. 91:2694-2701.

Welch, J. G. 1982. Rumination, particle size and passage from the rumen. J. Anim. Sci. 54:885-894. 
Yang, W. Z., and K. A. Beauchemin. 2007. Altering physically effective fiber intake through forage proportion and particle length: Chewing and ruminal pH. J. Dairy Sci. 90:2826-2838.

Yang, W. Z., and K. A. Beauchemin. 2009. Increasing physically effective fiber content of dairy cow diets through forage proportion versus forage chop length: Chewing and ruminal pH. J. Dairy Sci. 92:1603-1615.
Zebeli, Q., J. R. Aschenbach, M. Tafaj, and J. Boguhn. 2012. Role of physically effective fiber and estimation of dietary fiber adequacy in high-producing dairy cattle. J. Dairy Sci. 95:1041-1056.

Zebeli, Q., J. Dijkstra, M. Tafaj, H. Steingass, B. N. Ametaj, and W. Drochner. 2008. Modeling the adequacy of dietary fiber in dairy cows based on responses to ruminal $\mathrm{pH}$ and milk fat production to composition of the diet. J. Dairy Sci. 91:2046-2066. 